\title{
HOW TO WORK WITH THEMATIC TEXTS IN ESP CLASSES
}

\author{
Svitlana O. Chernyshova, Ph.D. in Philology \\ Olena A. Sydorenko, Ph.D. in Philology \\ Olena P. Tokmenko, Ph.D. in Pedagogy \\ Ukraine, Kyiv, \\ Institute of Philology, Taras Shevchenko National University of Kyiv
}

DOI: https://doi.org/10.31435/rsglobal_ws/30092019/6702

\begin{abstract}
ARTICLE INFO
Received: 19 July 2019

Accepted: 12 September 2019

Published: 30 September 2019

\section{KEYWORDS}

thematic text,

skill,

meaning,

lexical and grammatical rules, professionally oriented.

ABSTRACT

The article provides guidelines on working with thematic texts with students of non-linguistic majors. It seeks to formulate effective and efficient methods of working with thematic texts, drawing upon the main types of working with texts in general. The article has made use of the method of analysing thematic texts and, therefore, argues that there are three basic steps in working with thematic texts, namely pre-textual, textual, and post-textual. A set of exercises based on the book On the Uses of Philosophy by Will Durant has been used to illustrate the point. In the final analysis, the article argues that the methodology it sets out focuses on developing students' reading skills through helping them:

- correctly understand a foreign word;

- make conscious use of the structure of the meanings of foreign words;

- combine words and/or phrases in accordance with relevant lexical and grammatical rules;

- formulate and express an opinion in a foreign language in various form with thematic vocabulary;

- and understand thoughts expressed by other foreign-language speakers.
\end{abstract}

Citation: Svitlana O. Chernyshova, Olena A. Sydorenko, Olena P. Tokmenko. (2019) How to Work with Thematic Texts in Esp Classes. World Science. 9(49), Vol.1. doi: 10.31435/rsglobal_ws/30092019/6702

Copyright: (C) 2019 Svitlana O. Chernyshova, Olena A. Sydorenko, Olena P. Tokmenko. This is an openaccess article distributed under the terms of the Creative Commons Attribution License (CC BY). The use, distribution or reproduction in other forums is permitted, provided the original author(s) or licensor are credited and that the original publication in this journal is cited, in accordance with accepted academic practice. No use, distribution or reproduction is permitted which does not comply with these terms.

Introduction. Since any English for Specific Purposes (ESP) course is based on the majorspecific discipline, a thematic text is a high-quality and reliable cognitive material that complements the knowledge acquired in the course of the study and ensures that the prospective specialist has a decent command of the English language. The selection of educational material follows the provisions of the Common European Framework of Reference for Languages, which states that the basic principles of the selection of language-teaching tools provide for the selection of original texts, taking into account the professional needs of those studying a foreign language [1,81]. Hence, a thematic text is the main means of learning ESP; a source of thematic vocabulary; and a way of shaping the linguistic, professional and sociocultural competence of students by virtue of 'overlaying' foreign language skills on the substantive content of the profession while performing professional tasks [5, 199]. The lexical, grammatical and semantic fabric of the text forms an understanding and sense of the language, developing linguistic and cognitive skills.

Reading texts in English is one of the ways of learning the English language. Well-selected English texts significantly contribute not only to the enhancement of the linguistic competence but also to the motivation for the student to work independently. Reading texts can differ in terms of both their purposes and the ways in which such purposes are attained. The most common ones include replenishing general or thematic vocabulary; improving the pronunciation of English words and 
phrases; and revising the rules of English grammar through the analysis of typical examples available in the text. Attaining those purposes obviously requires selecting relevant English texts.

In terms of their thematic orientation, texts can be characterised by a large variety of grammatical forms and lexical material. The teacher can determine more accurately the students' knowledge of the foreign language and, accordingly, pick up the texts suitable for their level. Texts in English can be taken from specialised journals and newspapers or works written by experts in the field in question. Since student experience certain difficulties in processing a thematic text-due to their lack of linguistic and professional competence - the teacher must carefully plan the work with the text, identify potentially problematic parts, prepare methods for processing their basic lexical and grammatical features, and come up with a set of relevant exercises. Traditionally, working with the text includes three stages, namely pre-textual, textual, and post-textual $[2,4]$.

Research results. Let us consider the work with a thematic text by the example of $O n$ the Uses of Philosophy by Will Durant [7], intended for students of philosophy. There, the following stages can be identified:

1. Working with active vocabulary included in the text. Compiling a thematic dictionary to the text and working with this dictionary is one of the types of pre-text exercises that enable students to understand the main idea of the text and, subsequently, become the basis for understanding and acquiring new material. A thematic dictionary offers the lexical minimum, which makes it possible for students to speak on the given topic by providing the precise expression of thoughts and correct word usage. The lexical minimum can be used by students to read a thematic text with the accompanying task of studying the words and phrases on the given topic, finding in the text sentences with those words and phrases, and translating them, for example existence, meaningless, delight, incomparably, wistful, vacillation and futility, chaos, decipher, maelstrom, circumstance, inevitable, the creation of death.

In studying new words and phrases, it is necessary to follow a three-point plan: (a) finding out the meaning(s) of unfamiliar words and/or phrases, (b) writing them down and (c) learning the words and phrases by repetition. The first point (finding the meaning(s)) should not take up too much time if the following recommendations are applied: a word or phrase first has to be understood from its context, found in a bilingual dictionary or, should a student's vocabulary be sufficient, found in a monolingual dictionary. The general rule is to read the text carefully, clarifying the meaning(s) of each unfamiliar word or phrase.

Of particular interest at the pre-textual stage is the study of idiomatic expressions or phrasal verbs. In the first instance, it should be explained to students that they are rarely to be used in formal writing and are more attributable to colloquial speech or belle-lettres. Since such expressions and phrases do not directly correspond with lexical units in students' native language, they deserve special attention and care. The teacher may need to use additional materials in order to help students use idiomatic expressions correctly in their speech.

It is therefore advisable that a separate set of exercises be prepared for learning idioms and phrasal verbs, such as inserting prepositions and/or adverbs; finding synonyms for highlighted parts of the text from among given idioms and/or phrasal verbs; filling in gaps with correct phrasal verbs; etc.

2. Working with a thematic descriptive text. After initial difficulties in comprehending the text have been dealt with, students move on to reading the given thematic text. Working with such texts pursues the aim of developing students' reading, pronunciation and translation skills. At this stage, students are asked to read and translate the text.

After reading the text, students do lexical exercises with a view to revising and checking their understanding of the text. Of particular importance are lexical exercises that contribute to developing the ability of determining the meaning of a given word or phrase in a particular context; determining the role of words in the lexical system of language; and analysing the meaning of a keyword (or keywords) in a particular context. The exercises recommended after reading the text should be designed in a way so that students will use the words and/or phrases selected at the previous stage for translating, retelling, and discussing the text, both orally and in writing. Such exercises often include the task of writing down keywords from the given text; answering questions based upon the text; or making up a plan of the text with the help of new vocabulary.

3. Doing post-text exercises for revising the lexical minimum of the lesson, including translating English words and/or phrases into Ukrainian. This stage helps students compare lexical units of different languages and ascertain their meaning. Such post-text exercises may include choosing a keyword or keywords from the given text and/or making up sentences with one and/or more keywords. 
To take an example, the following is an exercise that checks students' ability to make up correct sentences and use new vocabulary in correct contexts:

Make up sentences using the following words:

A pleasure, the Mirages, There, and, a lure, in, of, even, metaphysics, is, philosophy, in.

Another example illustrates how exercises can be used to both check students' comprehension of the given text and understanding of new vocabulary:

\section{Detect the right statement:}

- Science is an analytical description; philosophy is emotional interpretation.

- The scientist is as interested in the leg of a blessing as in the creative throes of a genius.

- Philosophy seems to stand still, perplexed; but only because she leaves no fruits of victory to her daughters the sciences.

- Philosophy accepts the hard and hazardous task of dealing with problems not yet open to the methods of science - problems like good and evil, beauty and ugliness, order and freedom, life and death.

Some exercises require selectively learning the given text's context. They include the fill-inthe-gaps type of exercises, such as the following one:

\section{Complete the following sentences:}

But the philosopher is not content to describe the fact; he wishes to 1) its relation to experience in general, and thus to get its meaning and worth; he combines things in 2) ; he tries to put it together better than before, that 3) which the inquisitive scientist has analytically taken apart.

It should be noted, however, that plainly taking parts of the given text for such exercises should be avoided. The teacher is to paraphrase parts of the text so that such exercises should be effective. In addition, if options are provided for each gap in such exercises and students are asked to choose the correct option, the teacher may ask them to explain why they have chosen this option over the others. Let us take the sentence from the above exercise to illustrate the point:

But the philosopher is not content to describe the fact; he wishes to 1) its relation to experience in general, and thus to get its meaning and worth...
A. purify
B. ascertain
C. locate D. expand

There, students must explain why option B is the only correct one, drawing upon the lexical and grammatical contexts of the sentence, i.e. option A ("purify") cannot be lexically used with "relation", etc.

Another effective type of exercises checking the understanding of the given text involves identifying redundant words, such as:

Read the text below and decide which lines of the text contain unnecessary words.

\begin{tabular}{|c|l|c|}
\hline$\#$ & \multicolumn{1}{|c|}{ Line } & Tick \\
\hline 1 & In every field of activity there is a philosophy of it that involves in & \\
\hline 2 & questioning of its fundamental concepts, principles, and methods. & \\
\hline 3 & So, there is philosophy of science, philosophy of religion, philosophy of & \\
\hline 4 & art, and so on. Nearly always, some of the best between practitioners in & \\
\hline 5 & each field are interested in its philosophy. & \\
\hline
\end{tabular}

The system of recommended exercises may also include those aimed at explaining the meaning of some phrases from the text, as is shown by the following example:

Define the meaning of the phrase:

"To be a philosopher," said Thoreau, "is not merely to have subtle thoughts, nor even to find a school, but to love wisdom as it is to live, according to its dictates, a life of simplicity, independence, magnanimity, and trust."

With this type of exercises, a post-text discussion can be organised, where students express their ideas as to certain parts of the given text.

The above types of exercises can be used to check students' work on the adequate understanding of new vocabulary and the text in question, and to contribute to the active acquisition of new lexical material. They can be done and, consequently, checked both orally and in writing, taking little to no time during the lesson, which allows the teacher to effectively use the lesson time devoted to working with the thematic text.

It should be noted that, at this stage of working with a thematic text, the student is able to come up with a cohesive statement based upon the material of the text. Exercises of this type may 
include answering questions not directly related to the given text but based upon it, with arguments provided in favour of the answer given. This is the communicational method of checking not only a deeper understanding of the text, but also the student's ability to formulate clear statements on a specific topic in a particular context. On a more general level, in answering a question, students learn to choose from the text relevant vocabulary and link it to the situation in which it can be used; transform the linguistic material being studied; and use lexical units in various forms. Asking students to provide argument in favour of their opinion helps engage them in speech-related activities at different levels of language competence. These are open-ended exercises, i.e. tasks that do not have one correct answer and allow students to deal with them whatever their language proficiency is. The type of exercises in question can be formulated as follows:

\section{Can you add some more of your own to the information of the text?}

Skim the text quickly and write down what you can remember., etc.

Such exercises allow each student to give answers of the complexity and length that they are able to. Even an unprepared student can express his or her own point of view by doing them. This incentivises each student to participate in classwork, and develops their overall language skills. At the last stage of working with text, the teacher may give students the task of finding additional information or discussing the ideas formulated in the text.

Conclusions. The content derived from the given text and the system of relevant training exercises will form the basis for the development of competent dialogical and monological speech. Consequently, this leads to the next stage of working with the text, which involves processing information contained in the given text in order to formulate relevant, cohesive statements. The context of the text is used as the linguistic support for the development of students' linguistic skills as applicable in both oral and written speech. Formulating a statement based on the given text requires students to formulate the main idea of the text and select the relevant material from the text.

Therefore, lexical exercises formed on the basis of thematic texts are designed to develop students' lexical and linguistic competence. This allows students to correctly understand a foreign word; make conscious use of the structure of the meanings of foreign words; combine words and/or phrases in accordance with relevant lexical and grammatical rules; formulate and express an opinion in a foreign language in various form with thematic vocabulary; and, last but not least, understand thoughts expressed by other foreign-language speakers.

\section{REFERENCES}

1. Zahalnoieevropeiski rekomendatsii z movnoi osvity: vyvchennia, vykladannia, otsiniuvannia / nauk. red. ukrainskoho vydannia S. Yu. Nikolaieva. - K.: Lenvit, 2003. - 273 s.

2. Kalinina L. Getting America-Wise through reading. Navchalnyi posibnyk z anhliiskoi movy dlia studentiv vyshchhykh navchalnykh zakladiv. U 2-kh kn. / Kalinina L., Samoiliukevych I., Anderson K. - Kyiv: Ped. dumka, 2001. - Kn. 1. - 175 s.

3. Krat O. Komponenty systemy navchannia inozemnoi movy profesiynoho spriamuvannia cherez zmist profesiynoi diialnosti / O. I. Krat // Visnyk Dnipropetrovskoho universytetu imeni Alfreda Nobelia. - 2011. - № 2 (2). - S. 69-74. - (Seriia «Pedahohika i psykholohiia»).

4. Metodyka vykladannia inozemnykh mov u serednikh navchalnykh zakladakh: Pidruchnyk. Vyd. 2-e, vypr. i pererob. / za red. S. Yu. Nikolaievoi. - K.: Lenvit, 2002. - S. 328-350.

5. Sekret I. V. Model formuvannia inshomovnoi profesiinoi kompetentnosti v umovakh dystanciynoi osvity / I. V. Sekret // Visnyk LNU imeni Tarasa Shevchenka. - 2010. - № 17 (204). - S. 199-208.

6. Khrystova O. F. Vykorystannia fakhovykh tekstiv na zaniattiakh $\mathrm{z}$ angliyskoi movy za profesiynym spriamuvanniam / O. F. Khrystova // Naukovyi visnyk Melitopolskoho derzhavnoho pedahohichnoho universytetu imeni Bohdana Khmelnytskoho : zb. nauk. pr. - 2011. - № 6. - S. 220-225. - (Seriia «Pedahohika»).

7. The Story of Philosophy: navch. posibnyk z anhliyskoi movy / uporiadn. S. O. Chernyshova, O. P. Tokmenko. - K.: VPTs "Kyivskyi universytet", 2017. - 142 s. 